\title{
Correction: Learning from each other: $A B C$ transporter regulation by protein phosphorylation in plant and mammalian systems
}

\author{
Bibek Aryal*, Christophe Laurent* and Markus Geisler*1 \\ "Department of Biology - Plant Biology, University of Fribourg, Rue Albert Gockel 3, PER04, CH-1700 Fribourg, Switzerland
}

An incorrect version of the article was published in volume 43 (issue 5) 966-974 (doi: 10.1042/BST20150128); the correct version of the complete article is presented here.

\begin{abstract}
The ABC (ATP-binding cassette) transporter family in higher plants is highly expanded compared with those of mammalians. Moreover, some members of the plant ABCB subfamily display very high substrate specificity compared with their mammalian counterparts that are often associated with multidrug resistance (MDR) phenomena. In this review we highlight prominent functions of plant and mammalian $\mathrm{ABC}$ transporters and summarize our knowledge on their post-transcriptional regulation with a focus on protein phosphorylation. A deeper comparison of regulatory events of human cystic fibrosis transmembrane conductance regulator (CFTR) and ABCB1 from the model plant Arabidopsis reveals a surprisingly high degree of similarity. Both physically interact with orthologues of the FK506binding proteins (FKBPs) that chaperon both transporters to the plasma membrane in an action that seems to involve Hsp90. Further both transporters are phosphorylated at regulatory domains that connect both nucleotide-binding folds. Taken together it appears that ABC transporters exhibit an evolutionary conserved but complex regulation by protein phosphorylation, which apparently is, at least in some cases, tightly connected with protein-protein interactions (PPI).
\end{abstract}

Key words: ATP-binding cassette (ABC) transporter regulation, ABCB, FK506-binding protein (FKBP), P-glycoprotein, protein phosphorylation.

Abbreviations: ABA, abscisic acid; ABC, ATP-binding cassette; ADL, adrenoleukodystrophy; CFTR, cystic fibrosis transmembrane conductance regulator; CK2, casein kinase I; ER, endoplasmic reticulum; FKBP, FK506-binding protein; Hsp, heat shock protein; IAA, indole-3-acetic acid; IBA indolylbutyric acid; MDR, multidrug resistance; MDR, multidrug resistance; NBD, nucleotidebinding domain; PAT, polar auxin transport; PDR, pleiotropic drug resistance protein; PGP-1, P-glycoprotein 1; phot1, PHOTROPIN1; PID, PINOID; PIN, Pin-formed; PIS1, polar auxin transport inhibitor sensitive 1; PKA, protein kinase A; PKC, protein kinase C; PPI, protein-protein interaction; PPP2R3C, protein phosphatase $2 \mathrm{~A} \gamma$; SLC, solute carrier; SUR1/2, sulfonylurea receptor $1 / 2$; TMD, transmembrane domain; TPR, tetratricopeptide repeat; TWD1, TWISTED DWARF1; VLCFA, very long chain fatty acid; Ycf1, yeast cadmium factor 1.

${ }^{1}$ To whom correspondence should be addressed (email markus.geisler@unifr.ch).

\section{Importance of mammalian ABC transporters}

ATP-binding cassette $(\mathrm{ABC})$ transporters are integral membrane proteins ubiquitously present in all phyla [1]. They use the energy of nucleoside triphosphate (mainly ATP) hydrolysis to pump their substrates across the membrane [1]. The list of described substrates is long and diverse and includes metabolic products, sugars, metal ions, hormones, sterols, lipids and therapeutical drugs [1]. The ABC transport nano-machinery encompasses two transmembrane domains (TMDs) and two cytosolic nucleotide-binding domains (NBDs). ATP hydrolysis results in a conformational change of the NBDs, this in-turn brings the substrate across the membrane in a unidirectional fashion [2]. A total of 48 putative $\mathrm{ABC}$ transporters are encoded by the human genome and were shown to cluster into seven subfamilies (i.e. A-G) based on their domain assembly and phylogeny [3].

Most ABC transporters of the A subfamily, namely $\mathrm{ABCA}$, are involved in lipid transport processes in different mammalian body locations. ABCA1 has a notable role in cholesterol efflux and Tangier disease which is due to harbouring a mutation in the ABCA1 transporter [4-6]. Further, member 4 of the A subfamily (ABCA4) acts as a transporter of $\mathrm{N}$-retinylidene-phosphatidylethanolamine (NrPE). Malfunctioning of this transporter leads to the formation of lipid deposits in the macular region of the retina resulting in the Stargardt disease [7,8]. Mammalian ABCB1, also known as P-glycoprotein 1 (PGP1), is probably the best-characterized isoform of all ABCs: ABCB1 contributes to multidrug resistance (MDR) toward multiple cytotoxic chemotherapeutic agents when overexpressed in tumour cells $[9,10] . \mathrm{ABCB} 2 / \mathrm{TAP} 1$ and $\mathrm{ABCB} 3 / \mathrm{TAP} 2$ transporters are prominent members of the $\mathrm{B}$ subfamily, which are associated with the processing of antigens (TAPs) and function in the shuffling of peptides from the cytosol to the endoplasmic reticulum (ER) lumen [11,12].

The common and severe disease, cystic fibrosis (also called mucoviscidosis), is caused by highly prevalent point mutations in the cystic fibrosis transmembrane conductance regulator, $\mathrm{CFTR} / \mathrm{ABCC} 7$, an ATP-gated chloride ion channel [13-15]. ABCC2 is responsible for the transport of conjugated bilirubin across the plasma membrane. A mutation in ABCC2 leads to the accumulation of bilirubin 
and its conjugates in the liver and hence results in the DubinJohnson syndrome (DJS) [3,9,16,17]. Further, ABCC8 (SUR1) and ABCC9 (SUR2) are sulfonylurea receptors, which are the molecular targets of the sulfonylurea class of anti-diabetic drugs. The mechanism of SUR1 and SUR2 is to promote insulin release from pancreatic beta cells and a mutation in SUR1 is associated with permanent neonatal diabetes $[18,19]$.

Members of the ABCD subfamily are thought to localize in the peroxisomal membrane. A recent study showed that a dysfunction of the ABCD1 transporter is responsible for adrenoleukodystrophy (ADL). ADL is a $\mathrm{X}$ chromosomelinked disease, which is characterized by an impaired oxidation of very long chain fatty acids (VLCFA) in peroxisomes and hence the accumulation of VLCFA in tissues and body fluids $[3,9,20]$.

Some members of the ABCG subfamily, namely ABCG5 and ABCG8, are known to transport sterols. Defects in these transporters are responsible for sitosterolemis, which is characterized by the accumulation of plant sterols including cholesterol $[15,21,22]$. In analogy to ABCB1/PGP1 and $\mathrm{ABCC} 1 / \mathrm{MRP} 1$, the breast cancer resistance protein (BCRP/ABCG2), has been identified as MDR transporter and shown to transport diverse therapeutical drugs. Nevertheless, the physiological in vivo substrate remains unknown until now $[9,23]$.

In analogy to human $\mathrm{ABCB} 1$, also yeast and bacterial $\mathrm{ABC}$ transporters have been shown to play an important role in the degree of pathogenicity of the organism and to create MDR phenomena [4,24-28]. For instance, the pleiotropic Candida albicans $\mathrm{ABC}$ transporter, Cdr1 (Candida drug resistance 1), has been reported to be involved in the export of various drugs and antifungals and is known as homologue to the Saccharomyces cerevisiae PDR5 [26,29,30].

In summary, the study of mammalian $\mathrm{ABC}$ transporters has decoded the causes of several human diseases and provided us with essential insights in ABC functionality, allowing us to develop a range of successful disease treatments.

\section{Regulation of mammalian $A B C$ transporters by protein phosphorylation}

Being one of the most important post-translational modifications, protein phosphorylation plays also a significant role in the regulation of $\mathrm{ABC}$ transporters. This mode of action is fine-tuned by the antagonism between protein kinases and protein phosphatases adding or removing phosphate groups from the transporters respectively [31]. As such it is not surprising that point mutations of key phosphorylation sites are among the most prominent causes of some diseases, e.g. during cystic fibrosis [32]. However, not only mutations in the peptide sequence of the transporter itself are the cause of several conditions or diseases but also mutations in their regulators (e.g. protein kinases) can be the cause of grave physiological disorders [4,32].

The most common kinases known to be involved in human $\mathrm{ABC}$ transporter phosphorylation are protein kinase
A (PKA), protein kinase C (PKC) and the CK2 [4]. PKA for instance is involved in the regulation of $\mathrm{K}_{\mathrm{ATP}}$ channels by phosphorylating $\mathrm{ABCC} 8$ [33], whereas $\mathrm{ABCB} 1$ is a target of PKC $[34,35]$. Furthermore, ABCA1 has been shown to be regulated by $\mathrm{CK} 2$ [36]. These three kinases can act in concert, as was shown in the case of ABCC7/CFTR. Interestingly, although kinase mutations are suspected to be involved in several diseases [32], these events have not been associated with any ABC transporter related disease yet. This could be due to the fact that the majority of kinases regulating $\mathrm{ABC}$ proteins are also involved in apoptosis decisions [37-39]. Consequently, organisms lacking these regulators, or presenting mutated versions of these proteins, might not be viable.

Nevertheless, protein kinase inhibitors, such as plantderived flavonoids, have been investigated thoroughly in order to create new drugs against $\mathrm{ABC}$ transporter related diseases. Some flavonoids, like the flavonol quercetin $[40,41]$, were shown to block protein kinase activities $[40,41]$. Therefore for long the research focus was laid on finding flavonoids that would inhibit the export activity of transporters involved in MDR in order to render anticancer drugs more efficiently [41]; this approach is nicely reviewed in [41]. In contrast, some flavonoids, like genistein, were previously thought to act on tyrosine kinases but were later shown to activate CFTR by directly interacting with the latter [42]. However, genistein was shown to be not suitable for the treatment of cystic fibrosis because it interacts with various other targets besides CFTR [43-45], whereas higher concentrations have an inhibitory action $[42,43,46]$. Linking inhibitory effects to protein structures might be helpful in designing flavonoid-based drugs with fewer side effects [43].

A plethora of studies in yeast and bacteria support the idea that protein phosphorylation might be an universal regulatory event of $\mathrm{ABC}$ transporters [47]. In the bakers yeast, $S$. cerevisiae, ABC transporters STE6, YCF1, PDR5 and CDR1 have been suggested to be regulated by phosphorylation [48-53]. A comprehensive list of identified and tested phosphorylation sites found in $\mathrm{ABC}$ transporters from the model species Homo sapiens, S. cerevisiae and Arabidopsis thaliana is provided in Table 1. From this list it gets clear that most investigated sites have an impact on the transport capacity of individual transporters, although it is not always obvious if phosphorylation leads to an activation or inhibition. A second group of phosphorylation events affects protein stability and/or protein dimerization. In the following, we will focus on human ABCB1 and CFTR/ABCC7 phosphorylation; for a more detailed description of the impact of protein phosphorylation on other $\mathrm{ABC}$ transporters, we refer to the excellent review by Stolarczyk et al. [4].

Several lines of clinical evidence suggest ABCBs as general targets for phosphorylation-dependent regulation in the socalled linker region. This linker region connects the $\mathrm{N}$ terminal NBD1 of ABCBs with the TMD of the second half of the molecule (TMD2) and has been shown to regulate $\mathrm{ABCB}$ s by multiple phosphorylation events [54,55]. Linker 
Table 1 | List of experimentally confirmed ABC transporter phosphorylation sites in S. cerevisiae, H. sapiens and A. thaliana (n.i., not identified)

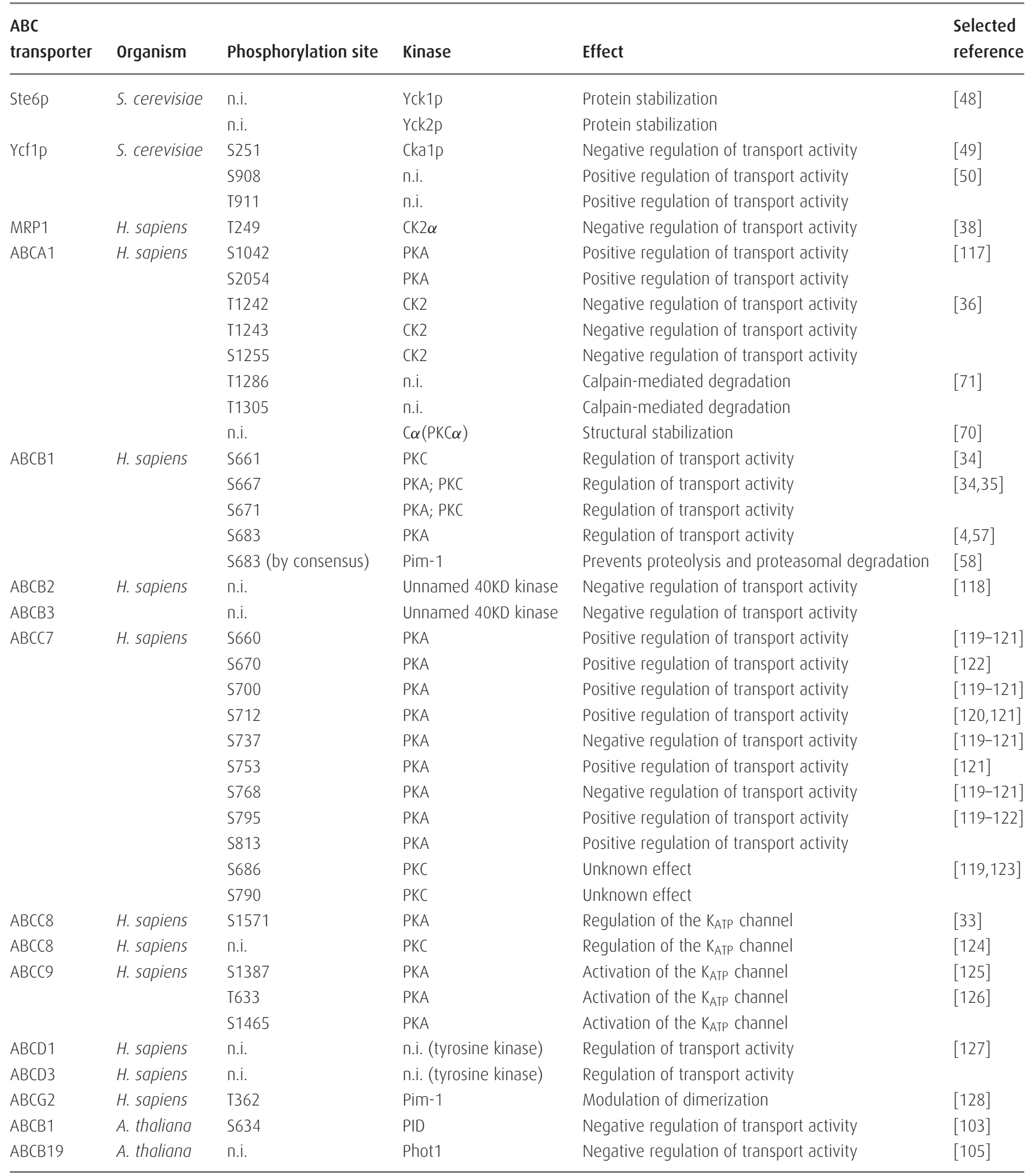

phosphorylation alters $\mathrm{ABCB}$ transport and associated ATPase activity [56]. An accumulation of serine residues was identified to be phosphorylated by PKC $[54,55,57]$ that regulate the drug transport properties [56]. In addition to $\mathrm{PKC}$, various publications suggest $\mathrm{ABCB} 1$ phosphorylation by PKA and CK2 but a significant conclusion has yet to be made $[4,34,35]$. Moreover, human ABCB1 was shown to be phosphorylated by Pim-1 kinase protecting ABCB1 from degradation and enabling its glycosylation and cell surface expression [58].

The regulatory $\mathrm{R}$ domain of $\mathrm{ABCC}$ transporters linking also NBD1 with TMD2 is a discrete domain unique for CFTR and its orthologues [59]. The R domain is another prominent target of their respective protein kinases $[4,35,60]$. The $\mathrm{Cl}^{-}$channel ABCC7 has been shown to be largely phosphorylated all over the $\mathrm{R}$ domain by protein kinases, 
PKA, PKC, CK2 and 5'-AMP-activated protein kinase (AMPK) $[3,15,61,62]$. Computational and NMR analyses indicate that phosphorylation results in a conformational change of the $\mathrm{R}$ domain and hence facilitates the opening of the core allowing ions to be transported $[4,63,64]$. Based on the well-studied regulation by PKA, it seems that there is the requirement for a specific phosphorylation pattern in the ABCC7 $\mathrm{R}$ domain [18]. This pattern needs to be formed in a specific series of phosphorylation events in order to activate the activity of ABCC7 successfully [18]. Furthermore, it has been shown that the different protein kinases are interdependent [61].

The regulatory subunit $\mathrm{B}$ of serine/threonine-specific protein phosphatase 2A $\gamma$ (PPP2R3C) plays a major role in the negative regulation for both, the expression and function of HsABCB1 [65]. Furthermore, it seems that in order to exert its dephosphorylating function correctly, PPP2R3C needs to form a complex with a second serine/threoninespecific protein phosphatase, namely PP5 [65]. This example demonstrates that protein-protein interaction (PPI) is a second important event during the regulation of $\mathrm{ABC}$ transporters. However, PPI is also required in other non-phosphorylation events. One of these mechanisms, the regulation of the correct post-translational protein folding and the subsequent trafficking is best illustrated using ABCC7 as example: CFTR interacts with the heat shock protein $\mathrm{Hsp} 90$ and the FK506-binding protein 38 (FKBP38/FKBP8). ABCC7 mutations lead to an improper folding and trafficking as wells as loss of stability of the protein and finally to an endoplasmic reticulum-associated degradation (ERAD) [66]. CFTR, while localized on the $\mathrm{ER}$, is retained by the chaperone function of Hsp90 [67]. Hutt et al. [66] provided evidence that subsequent to this interaction, FKBP38 is recruited to the complex through its Hsp90-interacting TPR domain and induces the liberation of CTFR from the Hsp90 complex [66,68]. Once having removed Hsp90 from the complex, FKPB38 is thought to interact with CFTR via its TPR domain before shifting the interacting domain towards its catalytic domain [66]. This interaction will probably allow FKPB38 to isomerize peptidyl prolyl bonds of CFTR, which will in return allow for the establishment of the final and functional protein structure of CFTR [66,69].

Phosphorylation of ABC transporters plays also an important role in protein stability [66]. This is supported by the finding that ABCA1 stabilization is dependent on protein kinase $\mathrm{PKC} \alpha[4,70,71]$.

Taken together, ABC transporters exhibit a tight and complex regulation by protein phosphorylation, which apparently is, at least in some cases, tightly connected with PPI, although the exact interconnecting mechanisms are currently not well understood.

\section{Role of $A B C$ transporters in plants}

The first role accredited to plant ABC transporters has been intracellular (vacuolar) detoxification in analogy to
PM export in mammalian cells [72,73]. However, since then the function of different members of the vast plant ABC transporter family was quickly extended [73]. Besides the sequestering of xenobiotic conjugates into the vacuole, there is plethora of $\mathrm{ABC}$ transporter substrates ranging from phytohormones (IAA, IBA, ABA and cytokinins), heavy metals, lipids, terpenoids, lignols and organic acids [74-77]. As a consequence, the roles of the members of the eight $\mathrm{ABC}$ subfamilies found in plants vary from plant development, over important physiological cues to pathogen response [73]. Since the ABC family in plants is so highly expanded (the model plant $A$. thaliana contains more than 120 ABC transporter genes [73]) and with it their functional diversity, we are going to focus in this review mainly on described regulatory functions that were derived from $A$. thaliana. For a more exhaustive description we refer to the excellent review by Kang et al. [73].

The classification of plant ABC transporters is in agreement with the nomenclature system known for their mammalian homologues and reflect their common evolutionary origin $[73,78]$. Hence, $\mathrm{ABC}$ proteins containing a TMD1NBD1-TMD2-NBD2 domain signature are classified into the $\mathrm{B}$ family [78,79]. Well-studied examples of this subfamily in A. thaliana are $\mathrm{ABCB} 1, \mathrm{ABCB} 19$ and $\mathrm{ABCB} 4$, whereas initial reports concern also $\mathrm{ABCB} 21$. All four were show to transport the plant hormone, auxin [chemically indole-3acetic acid (IAA)] [80-82]. Local gradients of IAA regulate plant growth and development and these gradients are created and maintained by the directional, cell-to-cell transport of IAA, in a process that is called polar auxin transport (PAT) [83]. This fascinating process is specific for higher plants and also not described for other plant hormones [84]. $\mathrm{ABCB} 1$ and $\mathrm{ABCB} 19$ were shown to function as IAA exporters functioning in the long-range transport of auxin [85], whereas ABCB4 and ABCB21 were characterized as facultative importers/exporters $[81,82,86]$. Interestingly, transport directionalities seem to be regulated by internal auxin concentrations [82]; a feature not yet described for any non-plant ABCB.

Another remarkable difference between plant and mammalian $\mathrm{ABCB}$ s lies in the fact that plant $\mathrm{ABCB}$ orthologues seem to own a far higher substrate specificity compared with their mammalian counterparts, especially upon overexpression in tumour cells [87]. Plant ABCB substrates are limited to a few native and synthetic auxins (and some organic acids) but do not transport any standard mammalian $\mathrm{ABCB}$ substrates even when they are expressed in mammalian cell cultures $[75,85,88]$. A molecular rationale for enhanced substrate specificities for plant $\mathrm{ABCBs}$ was recently given by the identification of kingdom-specific candidate substrate-binding regions within the translocation chamber formed by the TMDs of Arabidopsis ABCBs [89].

An involvement of ABCB1 and ABCB19 in PAT was originally based on the phenotype of the Arabidopsis $a b c b 1$ $a b c b 19$ double mutant, which combines strong dwarfism, a disoriented growth and a helical rotation of epidermal root 
Figure 1| Plant and mammalian ABCB1 linkers and phosphorylation sites are only weakly conserved

Relevant plant ABCB1 linker phosphorylation sites (green organism names) identified either by phosphoproteomics (black [116]) or experimentally (red [103]) are indicated by triangles above the alignment. Experimentally verified phosphorylation sites of mammalian ABCB1 orthologues (red organism names) that are target of PKC (blue) or PKA (green) are indicated below the alignment. Figure modified from [103]: Henrichs, S., Wang, B., Fukao, Y., Zhu, J., Charrier, L., Bailly, A., Oehring, S.C., Linnert, M., Weiwad, M., Endler, A. et al. (2012) Regulation of ABCB1/PGP1-catalysed auxin transport by linker phosphorylation. EMBO J. 31, 2965-2980.

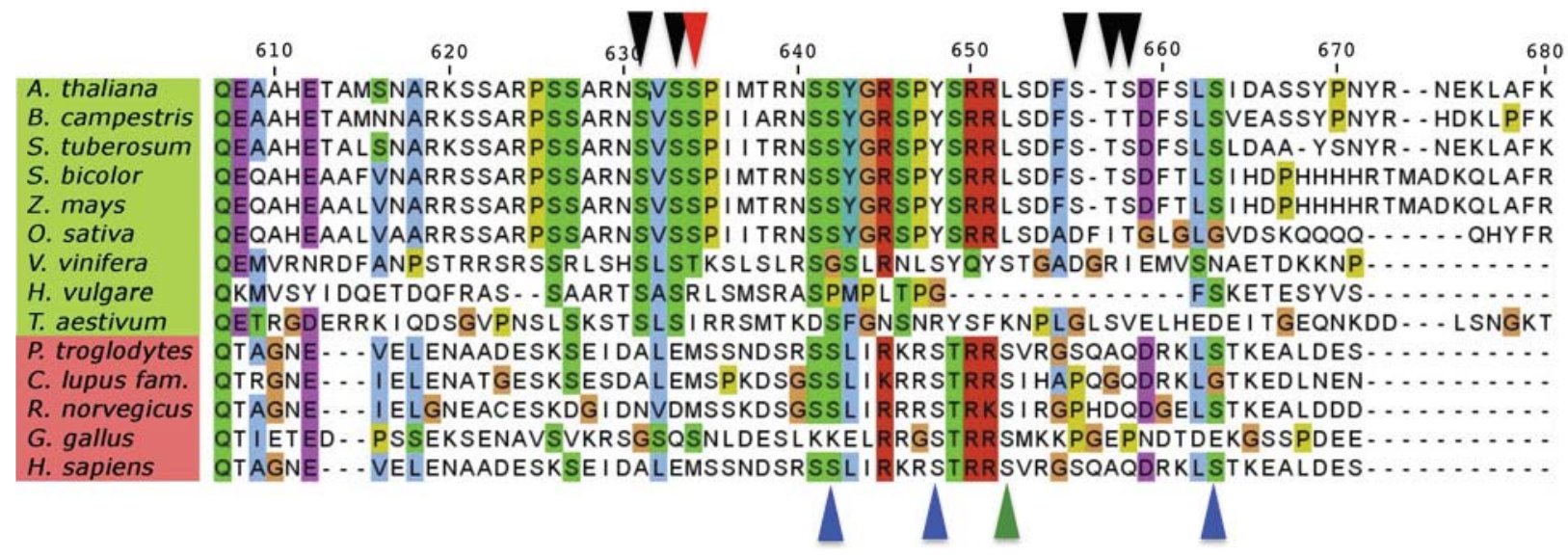

layers (twisting) [80]. In parallel, a similar phenotype was found for an Arabidopsis mutant lacking the functionality of the FKBP42, TWISTED DWARF1 (TWD1) $[85,90]$. In the last decade evidence was provided that $\mathrm{ABCB} 1$ and $\mathrm{ABCB} 19$ transport activity depends on the physical interaction with TWD1 [90,91]. As discussed above, similar interactions have been reported also for human ABCC7 and FKBP38; a mechanistic comparison will be addressed further down in this review. Interestingly, $\mathrm{ABCB} 1$ and $\mathrm{ABCB} 19$ were also shown to functionally interact with two permease-like members of the PIN (Pin-formed) family, PIN1 and PIN2 [88]. Both regulatory events stress the importance of PPI in the regulation of $\mathrm{ABC}$ transporters.

An additional vital function covered by the plant $\mathrm{ABC}$ transporter toolbox is their involvement in pathogen defense strategies. In Arabidopsis, member 36 of the ABC subfamily G (ABCG36/PDR8) is known for its pathogenic defense properties [92]. However, ABCG36 has also been reported for being involved in the transport of heavy metals, like cadmium [93]. A close ABCG36 homologue, ABCG37/PDR9/PIS1, was found to export a range of auxinic compounds, including the IAA precursor, indolylbutyric acid, IBA [94]. ABCG37 was shown also to be responsible for the export of phenolic compounds upon Fe deficiency [95]. Interestingly, both ABCG36 and ABCG37 reside on the outer lateral PM domain of epidermal root cells that defines the root and soil interface [94].

Recently, ABCG16 was reported to play a role in pathogen resistance against Pseudomonas syringae [96]. Furthermore, like for ABCG36, also for ABCG16 a second transport function was described that provides tolerance to the phytohormone, ABA (abscisic acid) [96]. Previously, ABCG25 was reported to export ABA from the cell, whereas
ABCG40/PDR12 seems to mediate the import into cells $[76,97]$

Therefore the question arises whether the ABCG transporter class has a broader substrate specificity as described for its yeast orthologues [98-100]. An alternative explanation is that putatively identified ABCG substrates, such as the phytohormones IBA or ABA, might act as compounds that bridge pathogen-related and developmental roles $[73,93]$.

Taken together, these two excerpts underline the impression that plant $\mathrm{ABC}$ transporters cover a very broad array of functions, although most of them still need to be uncovered compared with their mammalian counterparts.

\section{Regulation of plant $A B C$ transporters via protein phosphorylation}

As for their mammalian counterparts, recent advancements in phosphoproteomics have enabled large-scale analysis of plant $\mathrm{ABC}$ phosphopeptides from complex protein mixtures by LC-MS/MS [101,102]. A recent comparison of plant and mammalian ABCB1 linker domains has revealed, however, a very low degree of conservation both on the sequence levels and in respect to the described phosphorylation sites [103] (see Figure 1). This might reflect - beside the overall similar concept of $\mathrm{ABCB}$ regulation by linker phosphorylation - an evolutionary split. This is obviously also supported by the finding that classical isoforms of PKA, PKC and PKG do not exist in plants [104].

Beside these proteomics data, until today only two studies have studied in detail plant $\mathrm{ABC}$ regulation by protein phosphorylation. Both studies suggest that AGC kinases, PHOTROPIN1 (phot1) and PINOID (PID), have 
a direct impact on the auxin efflux activity of $\mathrm{ABCB} 19$ and $\mathrm{ABCB} 1$ respectively $[103,105]$. AGC kinases are plant orthologues of mammalian protein kinases A, C and G [104], however, evolutionary adaptations introduced specific structural changes within the AGC kinases that most likely allow modulation of kinase activity by external stimuli (e.g. light) [106].

The first report that plant $\mathrm{ABCB}$ are regulated by protein phosphorylation came from the finding that auxin efflux transporter $\mathrm{ABCB} 19$ is an interactor of the ACG4 kinase, phot1, acting as a PM-located blue light receptor [105]. Co-expression of phot1 in Hela cells reduced ABCB19 mediated auxin efflux, which is further enhanced by blue light irradiation, whereas ABCB1 activity remained unchanged [105].

Employing co-immunoprecipitation/LC-MS/MS and bioluminescence resonance energy transfer (BRET) analyses, the AGC3 kinase, PID, was characterized as a physical interactor of the FKBP42, TWD1. PID was shown to phosphorylate 6634 located in the linker domain of ABCB1 resulting in $\mathrm{ABCB} 1$ activation (see Figure 1). On the other hand, negative regulation of $\mathrm{ABCB} 1$ in the presence of TWD1 argues for a second, TWD1-specific ABCB1 phosphorylation by PID that does not essentially need to be part of the linker. As such TWD1 might function as a recruiting factor for $\mathrm{ABCB} 1$ phosphorylating protein kinases. Both modes of ABCB1 phosphorylation could take place in parallel or in competition resulting in the fine-tuning of $\mathrm{ABCB} 1$ as reported for mammalian $\mathrm{ABCBs}$ [18].

Interestingly, like mammalian $\mathrm{ABCB}$ s also plant $\mathrm{ABCB}$ are inhibited by flavonoids $[75,85]$. This is of interest because flavonols were suggested to act as non-essential regulators of auxin transport [107]. Further, flavonols, including quercetin, were shown to efficiently disrupt Arabidopsis ABCB1TWD1 interaction but not to bind to TWD1 [108], suggesting that plant $\mathrm{ABCB}$ regulation via flavonols might employ PPI. Obviously, in light of the fact that flavonols are also inhibiting protein kinases (such as PID) and the discussed ABCB1TWD1 and TWD1-PID interaction, these findings indicate that $\mathrm{ABCB}$ regulation via $\mathrm{PPI}$ and protein phosphorylation might be interconnected.

\section{Comparison of $H$. sapiens $A B C C 7$ and A. thaliana $\mathrm{ABCB} 1$ regulation}

As mentioned above, human ABCC7/CFTR is functionally interacting with $\mathrm{Hsp} 90$ and FKBP38 ensuring its correct folding [66] (see Figure 2). Moreover, chloride anion export activity and protein stability of $\mathrm{ABCC} 7$ is regulated via protein phosphorylation [66,109]. Finally, a third mode of regulation has been revealed by the correlation between defective CFTR proteins and decreased $\mathrm{HCO}_{3}{ }^{-}$ concentrations in anion/bicarbonate transporting epithelia, resulting in mucin precipitation during cystic fibrosis [61]. Members of the solute carrier (SLC) family 26, such as SLC26A3 or SLC26A6, interact with ABCC7 and export bicarbonate by exchanging chloride provided by ABCC7
[61]. Interaction with the $\mathrm{R}$ domain of ABCC7 is provided by the STAS (sulfate transporter and anti-sigma factor antagonist) domain in the C-terminus of SLC26 [61]. In order to bring these two domains in proximity and hence mediate the interaction, both proteins need to bind PDZ (postsynaptic density 95/discs large/zona occludens 1) domain containing adapter molecules [61].

Despite the fact that both transporters belong to different $\mathrm{ABC}$ families and species, these models of human ABCC7 regulation draws some remarkable parallels to the one of Arabidopsis ABCB1. The setup we are facing here is also composed of an FK506-binding protein (here: the FKBP42, TWD1), a protein kinase (here: the AGC3 kinase PID) and a permease-like protein of the PIN-family (see Figure 2). Like FKBP38, TWD1 is thought to chaperone ABCB1 during its secretion from the ER towards the PM [18]. Subsequently, PID is thought to be recruited by TWD1 and to phosphorylate ABCB1 [18]. PID is regulating the activity of ABCB1 by phosphorylating specific residues (such as S634) localized in its linker domain, the equivalent to the $\mathrm{R}$ domain of ABCC7 $[18,103]$. If protein phosphorylation via PID alters also protein stability of ABCB1 is currently not known.

The ABCBs-PIN pairings have significant effects on auxin transport capacity of the efflux complex [88]. In this respect it is worth mentioning that $\mathrm{ABCB} 19$ was recently shown to own an anion channel activity when expressed in HEK cells that was inhibited upon co-expression with TWD1 [110]. Although it is until now unclear if this exported anion is in fact IAA, this functional analogy is striking and fuelled by the finding that $A B C B 19$ was isolated in genetic screen using an anion channel blocker [80].

Another parallel is that like FKBP38 also TWD1 was shown to bind Hsp90 via its TPR domain [111], however, the relevance of this interaction is currently still unknown [112]. Further, a functional difference lies in the fact that TWD1 interacts with $\mathrm{ABCB} 1$ via its $\mathrm{N}$-terminal FKBD [90] and not with its TPR domain as ABCC7. The finding that vacuolar TWD1-ABCC1/ABCC2 interaction is mediated by the FKBD of TWD1 [113] suggests that this interacting domain is ABCC specific.

This regulatory Arabidopsis ABCB1 circuit is even more complicated by the finding that PID phosphorylation of PINs decides for their basal or apical fate [114]. Further, it was shown that PIN phosphorylation by PID also activates PIN activity [115]. Although all these interaction and phosphorylation events still need functional elucidations, they again pinpoint to the question which component is in the end functioning as auxin exporter, PINs or ABCBs individually, or both together. In the latter case an auxin efflux complex consisting of PIN-ABCB (and eventually also TWD1) would allow obviously for a fine-tuning of auxin transport activity and directionality [18].

In summary, based on this comparison it appears that nature is employing despite obvious physiological and mechanistic differences similar blue prints for the regulation of evolutionary distant $\mathrm{ABC}$ transporters in plants and mammals. Finally, we believe that cross-kingdom evaluations 
Figure 2 | Regulation of Arabidopsis ABCB1/PGP1 and human ABCC7/CFTR by FKBPs

Arabidopsis ABCB1 functionally interacts with PIN-like, secondary active auxin carriers on the PM. The FKBP42/TWD1 is essential for $A B C B 1$ activity and PM presence and acts as a chaperon for the ER-to-PM delivery of ABCB1. In analogy, the human orthologue of FKBP42, FKBP38, was shown to chaperone ABCC7/CFTR to the PM. Here it functionally interacts with bicarbonate $\left(\mathrm{HCO}_{3}{ }^{-}\right)$-chloride $\left(\mathrm{Cl}^{-}\right)$exchangers of the SLC26 family, leading to enhanced bicarbonate and thus fluid secretion. Note that phosphorylation of both linker and R-domains of ABCB1 and ABCC7 by the AGC kinase, PINOID and PKA, respectively, was shown to affect transport activity. Further, that the existence and identity of a counter-ion for PIN-mediated IAA transport is unclear; the same holds true for the involvement of Hsp90 shown to interact with the TPR domain of FKBP42. Figure modified from [18]: Geisler, M. (2014) It takes more than two to tango: regulation of plant ABC transporters. In Plant ABC transporters (Geisler, M., ed.), pp. 241-270, Springer, Switzerland.

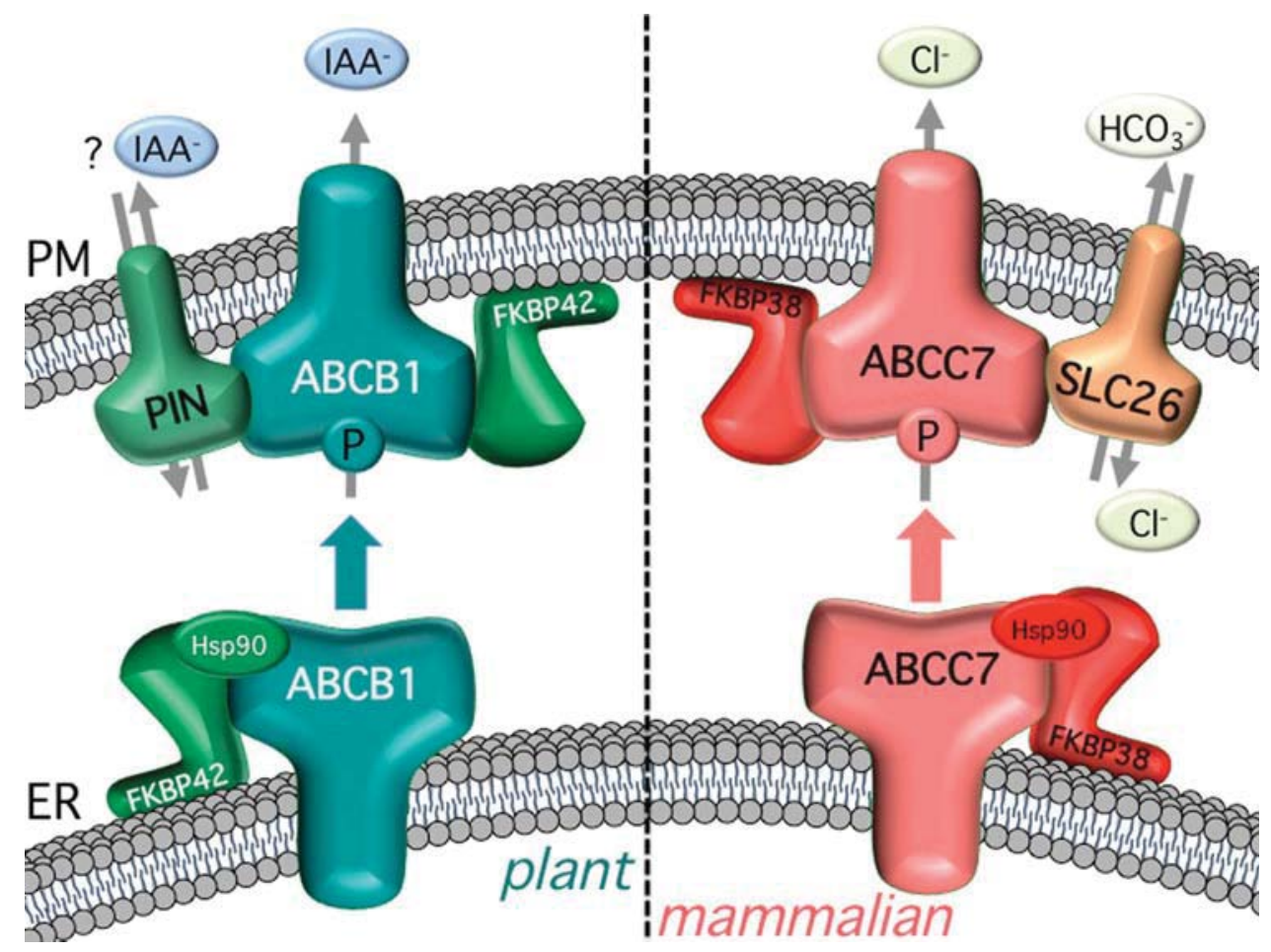

are very powerful sources to identify not only functional similarities but also, and maybe even more importantly, operative differences.

\section{Acknowledgements}

We thank plant and mammalian ABC transporter communities for their important contributions.

\section{Funding}

This work was supported by the Pool de Recherche of the University of Fribourg (to M.G.); and the Swiss National funds [grant number 31003A_144223 (to M.G.)].

\section{References}

1 Linton, K.J. (2007) Structure and function of ABC transporters. Physiology (Bethesda). 22, 122-130 CrossRef PubMed
2 Wilkens, S. (2015) Structure and mechanism of ABC transporters. F1000Prime Rep. 7, 14 CrossRef PubMed

3 Dean, M., Rzhetsky, A. and Allikmets, R. (2001) The human ATP-binding cassette (ABC) transporter superfamily. Genome Res. 11 1156-1166 CrossRef PubMed

4 Stolarczyk, E.I., Reiling, C.J. and Paumi, C.M. (2011) Regulation of ABC transporter function via phosphorylation by protein kinases. Curr. Pharm. Biotechnol. 12, 621-635 CrossRef PubMed

5 Brunham, L.R., Kang, M.H., Van Karnebeek, C., Sadananda, S.N., Collins, J.A., Zhang, L.-H., Sayson, B., Miao, F., Stockler, S., Frohlich, J. et al. (2015) Clinical, biochemical, and molecular characterization of novel mutations in ABCA1 in families with Tangier disease. JIMD Rep. 18, 51-62 CrossRef PubMed

6 Albrecht, C. and Viturro, E. (2007) The ABCA subfamily-gene and protein structures, functions and associated hereditary diseases. Pflugers Arch. 453, 581-589 CrossRef PubMed

7 Pollock, N.L. and Callaghan, R. (2011) The lipid translocase, ABCA4: seeing is believing. FEBS J. 278, 3204-3214 CrossRef Pubmed

8 Boye, S.E., Boye, S.L., Lewin, A.S. and Hauswirth, W.W. (2013) A comprehensive review of retinal gene therapy. Mol. Ther. $\mathbf{2 1}$ 509-519 CrossRef PubMed

9 Gottesman, M.M. and Ambudkar, S. V. (2001) Overview: ABC transporters and human disease. J. Bioenerg. Biomembr. 33, 453-458 CrossRef PubMed 
10 Ueda, K., Cornwell, M.M., Gottesman, M.M., Pastan, I., Roninson, I.B. Ling, V. and Riordan, J.R. (1986) The mdr1 gene, responsible for multidrug-resistance, codes for P-glycoprotein. Biochem. Biophys. Res. Commun. 141, 956-962 CrossRef PubMed

11 Parcej, D. and Tampé, R. (2010) ABC proteins in antigen translocation and viral inhibition. Nat. Chem. Biol. 6, 572-580 CrossRef PubMed

12 Seyffer, F. and Tampé, R. (2015) ABC transporters in adaptive immunity. Biochim. Biophys. Acta 1850, 449-460 CrossRef $\underline{\text { PubMed }}$

13 Cheng, S.H., Rich, D.P., Marshall, J., Gregory, R.J., Welsh, M.J. and Smith, A.E. (1991) Phosphorylation of the R domain by CAMP-dependent protein kinase regulates the CFTR chloride channel. Cell 66, 1027-1036 CrossRef PubMed

14 Nagel, G. (1999) Differential function of the two nucleotide binding domains on cystic fibrosis transmembrane conductance regulator. Biochim. Biophys. Acta - Biomembr. 1461, 263-274 CrossRef

15 Dean, M. and Annilo, T. (2005) Evolution of the ATP-binding cassette $(A B C)$ transporter superfamily in vertebrates. Annu. Rev. Genomics Hum. Genet. 6, 123-142 CrossRef PubMed

16 Keitel, V., Nies, A.T., Brom, M., Hummel-Eisenbeiss, J., Spring, H. and Keppler, D. (2003) A common Dubin-Johnson syndrome mutation impairs protein maturation and transport activity of MRP2 (ABCC2). Am. J. Physiol. Gastrointest. Liver Physiol. 284, G165-G174 CrossRef Pubmed

17 Keppler, D. and König, J. (2000) Hepatic secretion of conjugated drugs and endogenous substances. Semin. Liver Dis. 20, 265-272 CrossRef PubMed

18 Geisler, M. and Geisler, M. (2014) It takes more than two to tango: regulation of plant ABC transporters. In Plant ABC Transporters (, ed.), pp. 241-270, Springer, Switzerland

19 Proks, P., Shimomura, K., Craig, T.J., Girard, C.A.J. and Ashcroft, F.M (2007) Mechanism of action of a sulphonylurea receptor SUR1 mutation (F132L) that causes DEND syndrome. Hum. Mol. Genet. 16 2011-2019 CrossRef PubMed

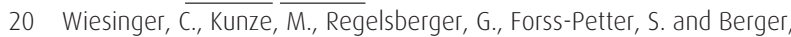
J. (2013) Impaired very long-chain acyl-CoA $\beta$-oxidation in human $X$-linked adrenoleukodystrophy fibroblasts is a direct consequence of ABCD1 transporter dysfunction. J. Biol. Chem. 288, 19269-19279 CrossRef PubMed

21 Berge, K.E. (2000) Accumulation of dietary cholesterol in sitosterolemia caused by mutations in adjacent ABC transporters. Science 290, 1771-1775 CrossRef PubMed

22 Kerr, I.D., Haider, A.J. and Gelissen, I.C. (2011) The ABCG family of membrane-associated transporters: you don't have to be big to be mighty. Br. J. Pharmacol. 164, 1767-1779 CrossRef PubMed

23 Woodward, O.M., Köttgen, A. and Köttgen, M. (2011) ABCG transporters and disease. FEBS I. 278, 3215-3225 CrossRef PubMed

24 Kiran, M.D., Akiyoshi, D.E., Giacometti, A., Cirioni, O., Scalise, G. and Balaban, N. (2009) OpuC - an ABC transporter that is associated with Staphylococcus aureus pathogenesis. Int. J. Artif. Organs 32, 600-610 Pubmed

25 Lamarche, M.G., Wanner, B.L., Crépin, S. and Harel, J. (2008) The phosphate regulon and bacterial virulence: a regulatory network connecting phosphate homeostasis and pathogenesis. FEMS Microbiol. Rev. 32, 461-473 CrossRef PubMed

26 Mishra, N., Prasad, T., Sharma, N., Payasi, A., Prasad, R., Gupta, D. and Singh, R. (2007) Pathogenicity and drug resistance in Candida albicans and other yeast species. Acta Microbiol. Immunol. Hung. 54, 201-235 CrossRef PubMed

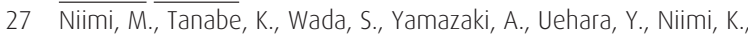
Lamping, E., Holmes, A.R., Monk, B.C. and Cannon, R.D. (2005) ABC transporters of pathogenic fungi: recent advances in functional analyses. Nihon Ishinkin Gakkai Zasshi 46, 249-260 CrossRef PubMed

28 Davidson, A.L. and Chen, J. (2004) ATP-binding cassette transporters in bacteria. Annu. Rev. Biochem. 73, 241-268 CrossRef PubMed

29 Prasad, R., De Wergifosse, P., Goffeau, A. and Balzi, E. (1995) Molecular cloning and characterization of a novel gene of Condido albicans, CDR1, conferring multiple resistance to drugs and antifungals. Curr. Genet. 27, 320-329 CrossRef PubMed

30 Krishnamurthy, S., Gupta, V., Snehlata, P. and Prasad, R. (1998) Characterisation of human steroid hormone transport mediated by cdr1p, a multidrug transporter of Condida albicans, belonging to the ATP binding cassette super family. FEMS Microbiol. Lett. 158, 69-74 CrossRef PubMed

31 Hunter, T. (1995) Protein kinases and phosphatases: the Yin and Yang of protein phosphorylation and signaling. Cell 80, 225-236 crossRef Pubmed
32 Cohen, P. (2001) The role of protein phosphorylation in human health and disease. Eur. J. Biochem. 268, 5001-5010 CrossRef PubMed

33 Béguin, P., Nagashima, K., Nishimura, M., Gonoi, T. and Seino, S. (1999) PKA-mediated phosphorylation of the human K(ATP) channel: separate roles of Kir6.2 and SUR1 subunit phosphorylation. EMBO J. 18, 4722-4732 CrossRef PubMed

34 Chambers, T., Pohl, J., Raynor, R. and Kuo, J. (1993) Identification of specific sites in human P-glycoprotein phosphorylated by protein kinase C. J. Biol. Chem. 268, 4592-4595 PubMed

35 Chambers, T., Pohl, J., Glass, D. and Kuo, J. (1994) Phosphorylation by protein kinase $\mathrm{C}$ and cyclic AMP-dependent protein kinase of synthetic peptides derived from the linker region of human P-glycoprotein. Biochem. J. 299, 309-315 CrossRef PubMed

36 Roosbeek, S., Peelman, F., Verhee, A., Labeur, C., Caster, H., Lensink, M.F., Cirulli, C., Grooten, J., Cochet, C., Vandekerckhove, J. et al. (2004) Phosphorylation by protein kinase CK2 modulates the activity of the ATP binding cassette A1 transporter. J. Biol. Chem. 279, 37779-37788 CrossRef Pubmed

37 Tan, Y., Demeter, M.R., Ruan, H. and Comb, M.J. (2000) BAD Ser-155 phosphorylation regulates BAD/BCl-XL interaction and cell survival. J. Biol. Chem. 275, 25865-25869 CrossRef PubMed

38 Stolarczyk, E.I., Reiling, C.J., Pickin, K.A., Coppage, R., Knecht, M.R. and Paumi, C.M. (2012) Casein kinase $2 \alpha$ regulates multidrug resistance-associated protein 1 function via phosphorylation of Thr249. Mol. Pharmacol. 82, 488-499 CrossRef PubMed

39 Doller, A., Huwiler, A., Müller, R., Radeke, H.H., Pfeilschifter, J. and Eberhardt, W. (2007) Protein kinase C alpha-dependent phosphorylation of the mRNA-stabilizing factor HuR: implications for posttranscriptional regulation of cyclooxygenase-2. Mol. Biol. Cell 18, 2137-2148 CrossRef PubMed

40 Masatoshi, H., Shigeo, I., Toshio, T., Kazuo, N., Masaaki, I. and Hiroyoshi, H. (1988) Differential effects of flavonoids as inhibitors of tyrosine protein kinases and serine/threonine protein kinases. Biochem. Pharmacol. 37, 2987-2992 CrossRef PubMed

41 Di Pietro, A., Conseil, G., Pérez-Victoria, J.M., Dayan, G., Baubichon-Cortay, H., Trompier, D., Steinfels, E., Jault, J.-M., de Wet, H., Maitrejean, M. et al. (2002) Modulation by flavonoids of cell multidrug resistance mediated by P-glycoprotein and related ABC transporters. Cell. Mol. Life Sci. 59, 307-322 CrossRef PubMed

42 Weinreich, F., Wood, P.G., Riordan, J.R. and Nagel, G. (1997) Direct action of genistein on CFTR. Pflügers Arch. Eur. J. Physiol. 434, 484-491 CrossRef

43 Hwang, T.-C. and Sheppard, D.N. (1999) Molecular pharmacology of the CFTR $\mathrm{Cl}^{-}$channel. Trends Pharmacol. Sci. 20,448-453 CrossRef Pubmed

44 Schultz, B.D., Singh, A.K., Devor, D.C. and Bridges, R.J. (1999) Pharmacology of CFTR chloride channel activity. Physiol. Rev. 79, S109-S144 PubMed

45 Illek, B., Fischer, H., Santos, G.F., Widdicombe, J.H., Machen, T.E. and Reenstra, W.W. (1995) CAMP-independent activation of CFTR Cl channels by the tyrosine kinase inhibitor genistein. Am. J. Physiol. Cell Physiol. 268, (886-893

46 Wang, F. (1998) Actions of genistein on cystic fibrosis transmembrane conductance regulator channel gating. Evidence for two binding sites with opposite effects. J. Gen. Physiol. 111, 477-490 CrossRef PubMed

47 Paumi, C.M., Chuk, M., Snider, J., Stagljar, I. and Michaelis, S. (2009) ABC transporters in Socchoromyces cerevisioe and their interactors: new technology advances the biology of the ABCC (MRP) subfamily. Microbiol. Mol. Biol. Rev. 73, 577-593 CrossRef PubMed

48 Kelm, K.B., Huyer, G., Huang, I.C. and Michaelis, S. (2004) The internalization of yeast Ste6p follows an ordered series of events involving phosphorylation, ubiquitination, recognition and endocytosis. Traffic 5, 165-180 CrossRef PubMed

49 Paumi, C.M., Chuk, M., Chevelev, I., Stagljar, I. and Michaelis, S. (2008) Negative regulation of the yeast ABC transporter Ycf1p by phosphorylation within its N-terminal extension. J. Biol. Chem. 283, 27079-27088 CrossRef PubMed

50 Eraso, P., Martínez-Burgos, M., Falcón-Pérez, J.M., Portillo, F. and Mazón, M.J. (2004) Ycf1-dependent cadmium detoxification by yeast requires phosphorylation of residues Ser908 and Thr911. FEBS Lett. 577, 322-326 CrossRef PubMed

51 Decottignies, A., Owsianik, G. and Ghislain, M. (1999) Casein kinase I-dependent phosphorylation and stability of the yeast multidrug transporter Pdr5p. J. Biol. Chem. 274, 37139-37146 CrossRef PubMed 
52 Wada, S.-I., Niimi, M., Niimi, K., Holmes, A.R., Monk, B.C., Cannon, R.D. and Uehara, Y. (2002) Candida glabrata ATP-binding cassette transporters Cdr1p and Pdh1p expressed in a Saccharomyces cerevisioe strain deficient in membrane transporters show phosphorylation-dependent pumping properties. J. Biol. Chem. 277 46809-46821 CrossRef PubMed

53 Wada, S., Tanabe, K., Yamazaki, A., Niimi, M., Uehara, Y., Niimi, K., Lamping, E., Cannon, R.D. and Monk, B.C. (2005) Phosphorylation of candida glabrata ATP-binding cassette transporter Cdr1p regulates drug efflux activity and ATPase stability. J. Biol. Chem. 280, 94-103 CrossRef PubMed

54 Conseil, G., Perez-Victoria, J.M., Jault, J.-M., Gamarro, F., Goffeau, A. Hofmann, J. and Di Pietro, A. (2001) Protein kinase C effectors bind to multidrug $A B C$ transporters and inhibit their activity. Biochemistry $\mathbf{4 0}$ 2564-2571 CrossRef PubMed

55 Chambers, T.C., Chalikonda, I. and Eilon, G. (1990) Correlation of protein kinase C translocation, P-glycoprotein phosphorylation and reduced drug accumulation in multidrug resistant human KB cells. Biochem. Biophys. Res. Commun. 169, 253-259 CrossRef PubMed

56 Szabó, K., Bakos, E., Welker, E., Müller, M., Goodfellow, H.R., Higgins, C.F., Váradi, A. and Sarkadi, B. (1997) Phosphorylation site mutations in the human multidrug transporter modulate its drug-stimulated ATPase activity. J. Biol. Chem. 272, 23165-23171 CrossRef PubMed

57 Orr, G.A., Han, E.K., Browne, P.C., Nieves, E., O'Connor, B.M., Yang, C.P. and Horwitz, S.B. (1993) Identification of the major phosphorylation domain of murine mdr1b P-glycoprotein. Analysis of the protein kinase $A$ and protein kinase C phosphorylation sites. J. Biol. Chem. 268, 25054-25062 PubMed

58 Xie, Y., Burcu, M., Linn, D.E., Qiu, Y. and Baer, M.R. (2010) Pim-1 kinase protects P-glycoprotein from degradation and enables its glycosylation and cell surface expression. Mol. Pharmacol. 78, 310-318 crossRef PubMed

59 Sebastian, A., Rishishwar, L., Wang, J., Bernard, K.F., Conley, A.B. McCarty, N.A. and Jordan, I.K. (2013) Origin and evolution of the cystic fibrosis transmembrane regulator protein R domain. Gene $\mathbf{5 2 3}$ 137-146 CrossRef PubMed

60 Seibert, F.S., Chang, X.-B., Aleksandrov, A.A., Clarke, D.M., Hanrahan, J.W. and Riordan, J.R. (1999) Influence of phosphorylation by protein kinase A on CFTR at the cell surface and endoplasmic reticulum. Biochim. Biophys. Acta 1461, 275-283 CrossRef PubMed

61 Fong, P. (2012) CFTR-SLC26 transporter interactions in epithelia. Biophys. Rev. 4, 107-116 CrossRef PubMed

62 Hegedus, T., Aleksandrov, A., Mengos, A., Cui, L., Jensen, T.J. and Riordan, J.R. (2009) Role of individual R domain phosphorylation sites in CFTR regulation by protein kinase A. Biochim. Biophys. Acta 1788, 1341-1349 CrossRef PubMed

63 Kanelis, V., Hudson, R.P., Thibodeau, P.H., Thomas, P.J. and Forman-Kay, J.D. (2010) NMR evidence for differential phosphorylation-dependent interactions in WT and DeltaF508 CFTR. EMBO J. 29, 263-277 CrossRef PubMed

64 Hegedus, T., Serohijos, A.W.R., Dokholyan, N.V, He, L. and Riordan, J.R. (2008) Computational studies reveal phosphorylation-dependent changes in the unstructured R domain of CFTR. J. Mol. Biol. 378, 1052-1063 CrossRef PubMed

65 Katayama, K., Yamaguchi, M., Noguchi, K. and Sugimoto, Y. (2014) Protein phosphatase complex PP5/PPP2R3C dephosphorylates P-glycoprotein/ABCB1 and down-regulates the expression and function. Cancer Lett. 345, 124-131 CrossRef PubMed

66 Hutt, D.M., Roth, D.M., Chalfant, M.A., Youker, R.T., Matteson, J., Brodsky, J.L. and Balch, W.E. (2012) FK506 binding protein 8 peptidylprolyl isomerase activity manages a late stage of cystic fibrosis transmembrane conductance regulator (CFTR) folding and stability. J. Biol. Chem. 287, 21914-21925 CrossRef PubMed

67 Loo, M.A., Jensen, T.J., Cui, L., Hou, Y., Chang, X.B. and Riordan, J.R. (1998) Perturbation of Hsp90 interaction with nascent CFTR prevents its maturation and accelerates its degradation by the proteasome. EMBO J. 17, 6879-6887 CrossRef PubMed

68 Edlich, F., Erdmann, F., Jarczowski, F., Moutty, M.-C., Weiwad, M. and Fischer, G. (2007) The Bcl-2 regulator FKBP38-calmodulin-Ca ${ }^{2+}$ is inhibited by Hsp90. J. Biol. Chem. 282, 15341-15348 crossRef PubMed

69 Jakob, R.P., Zoldák, G., Aumüller, T. and Schmid, F.X. (2009) Chaperone domains convert prolyl isomerases into generic catalysts of protein folding. Proc. Natl. Acad. Sci. U.S.A. 106, 20282-20287 crossRef Pubmed
70 Yamauchi, Y., Hayashi, M., Abe-Dohmae, S. and Yokoyama, S. (2003) Apolipoprotein A-I activates protein kinase C alpha signaling to phosphorylate and stabilize ATP binding cassette transporter A1 for the high density lipoprotein assembly. J. Biol. Chem. $\mathbf{2 7 8}$ 47890-47897 CrossRef Pubmed

71 Martinez, L.O., Agerholm-Larsen, B., Wang, N., Chen, W. and Tall, A.R. (2003) Phosphorylation of a pest sequence in ABCA1 promotes calpain degradation and is reversed by ApoA-I. J. Biol. Chem. 278 37368-37374 CrossRef PubMed

72 Martinoia, E., Grill, E., Tommasini, R., Kreuz, K. and Amrhein, N. (1993) ATP-dependent glutathione $S$-conjugate "export" pump in the vacuolar membrane of plants. Nature 364, 247-249 CrossRef

73 Kang, J., Park, J., Choi, H., Burla, B., Kretzschmar, T., Lee, Y. and Martinoia, E. (2011) Plant ABC transporters. Arabidopsis Book $\mathbf{9}$, e0153 CrossRef PubMed

74 Gaillard, C., Dufaud, A., Tommasini, R., Kreuz, K., Amrhein, N. and Martinoia, E. (1994) A herbicide antidote (safener) induces the activity of both the herbicide detoxifying enzyme and of a vacuolar transporter for the detoxified herbicide. FEBS Lett. 352, 219-221 crossRef PubMed

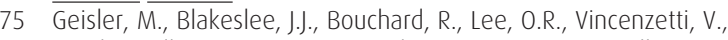
Bandyopadhyay, A., Titapiwatanakun, B., Peer, W.A., Bailly, A., Richards, E.L. et al. (2005) Cellular efflux of auxin catalyzed by the Arabidopsis MDR/PGP transporter AtPGP1. Plant J. 44, 179-194 CrossRef PubMed

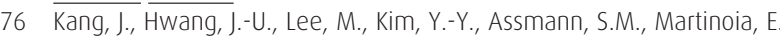
and Lee, Y. (2010) PDR-type ABC transporter mediates cellular uptake of the phytohormone abscisic acid. Proc. Natl. Acad. Sci. U.S.A. 107 2355-2360 CrossRef PubMed

77 Sparkes, I.A., Brandizzi, F., Slocombe, S.P., El-Shami, M., Hawes, C. and Baker, A. (2003) An Arobidopsis pex10 null mutant is embryo lethal, implicating peroxisomes in an essential role during plant embryogenesis. Plant Physiol. 133, 1809-1819 CrossRef PubMed

78 Verrier, P.J., Bird, D., Burla, B., Dassa, E., Forestier, C., Geisler, M., Klein, M., Kolukisaoglu, U., Lee, Y., Martinoia, E. et al. (2008) Plant ABC proteins - a unified nomenclature and updated inventory. Trends Plant Sci. 13, 151-159 CrossRef PubMed

79 Sánchez-Fernández, R., Davies, T.G., Coleman, J.0. and Rea, P.A. (2001) The Arabidopsis thaliano ABC protein superfamily, a complete inventory. J. Biol. Chem. 276, 30231-302344 CrossRef PubMed

80 Noh, B., Murphy, A.S. and Spalding, E.P. (2001) Multidrug resistance-like genes of Arabidopsis required for auxin transport and auxin-mediated development. Plant Cell 13, 2441-2454 crossRef PubMed

81 Santelia, D., Vincenzetti, V., Azzarello, E., Bovet, L., Fukao, Y., Düchtig, P., Mancuso, S., Martinoia, E. and Geisler, M. (2005) MDR-like ABC transporter AtPGP4 is involved in auxin-mediated lateral root and root hair development. FEBS Lett. 579, 5399-5406 CrossRef PubMed

82 Kamimoto, Y., Terasaka, K., Hamamoto, M., Takanashi, K., Fukuda, S., Shitan, N., Sugiyama, A., Suzuki, H., Shibata, D., Wang, B. et al. (2012) Arabidopsis ABCB21 is a facultative auxin importer/exporter regulated by cytoplasmic auxin concentration. Plant Cell Physiol. $\mathbf{5 3}$ 2090-2100 CrossRef PubMed

83 Friml, J. (2003) Auxin transport-shaping the plant. Curr. Opin. Plant Biol. 6, 7-12 CrossRef PubMed

84 Zazímalová, E., Krecek, P., Skủpa, P., Hoyerová, K. and Petrásek, J. (2007) Polar transport of the plant hormone auxin - the role of PIN-FORMED (PIN) proteins. Cell. Mol. Life Sci. 64, 1621-1637 CrossRef PubMed

85 Bouchard, R., Bailly, A., Blakeslee, J.J., Oehring, S.C., Vincenzetti, V., Lee, O.R., Paponov, I., Palme, K., Mancuso, S., Murphy, A.S. et al. (2006) Immunophilin-like TWISTED DWARF1 modulates auxin efflux activities of Arabidopsis P-glycoproteins. J. Biol. Chem. 281, 30603-30612 CrossRef PubMed

86 Terasaka, K., Blakeslee, J.J., Titapiwatanakun, B., Peer, W.A., Bandyopadhyay, A., Makam, S.N., Lee, O.R., Richards, E.L., Murphy, A.S., Sato, F. et al. (2005) PGP4, an ATP binding cassette P-glycoprotein, catalyzes auxin transport in Arabidopsis thaliono roots. Plant Cell 17, 2922-2939 CrossRef PubMed

87 O'Connor, R., Clynes, M., Dowling, P., O'Donovan, N. and O'Driscoll, L. (2007) Drug resistance in cancer - searching for mechanisms, markers and therapeutic agents. Expert Opin. Drug Metab. Toxicol. 3, 805-817 crossRef Pubmed 
88 Blakeslee, I.J., Bandyopadhyay, A., Lee, 0.R., Mravec, J., Titapiwatanakun, B., Sauer, M., Makam, S.N., Cheng, Y., Bouchard, R., Adamec, J. et al. (2007) Interactions among PIN-FORMED and P-glycoprotein auxin transporters in Arabidopsis. Plant Cell $\mathbf{1 9}$ 131-147 CrossRef PubMed

89 Bailly, A., Yang, H., Martinoia, E., Geisler, M. and Murphy, A.S. (2012) Plant lessons: exploring ABCB functionality through structural modeling. Front. Plant Sci. 2, 108 CrossRef PubMed

90 Geisler, M., Kolukisaoglu, H.U., Bouchard, R., Billion, K., Berger, I., Saal, B., Frangne, N., Koncz-Kalman, Z., Koncz, C., Dudler, R. et al. (2003) TWISTED DWARF1, a unique plasma membrane-anchored immunophilin-like protein, interacts with Arabidopsis multidrug resistance-like transporters AtPGP1 and AtPGP19. Mol. Biol. Cell 14, 4238-4249 CrossRef PubMed

91 Wang, B., Bailly, A., Zwiewka, M., Henrichs, S., Azzarello, E., Mancuso, S., Maeshima, M., Friml, J., Schulz, A. and Geisler, M. (2013) Arabidopsis TWISTED DWARF1 functionally interacts with auxin exporter ABCB1 on the root plasma membrane. Plant Cell $\mathbf{2 5}$ 202-214 CrossRef PubMed

92 Stein, M., Dittgen, J., Sánchez-Rodríquez, C., Hou, B.-H., Molina, A Schulze-Lefert, P., Lipka, V. and Somerville, S. (2006) Arabidopsis PEN3/PDR8, an ATP binding cassette transporter, contributes to nonhost resistance to inappropriate pathogens that enter by direct penetration. Plant Cell 18, 731-746 CrossRef PubMed

93 Kim, D.-Y., Bovet, L., Maeshima, M., Martinoia, E. and Lee, Y. (2007) The ABC transporter AtPDR8 is a cadmium extrusion pump conferring heavy metal resistance. Plant J 50, 207-218 CrossRef PubMed

94 Ruzicka, K., Strader, L.C., Bailly, A., Yang, H., Blakeslee, J., Langowski, L., Nejedlá, E., Fujita, H., Itoh, H., Syono, K. et al. (2010) Arabidopsis PIS1 encodes the ABCG37 transporter of auxinic compounds including the auxin precursor indole-3-butyric acid. Proc. Natl. Acad. Sci. U.S.A. 107, 10749-10753 CrossRef PubMed

95 Fourcroy, P., Sisó-Terraza, P., Sudre, D., Savirón, M., Reyt, G., Gaymard, F., Abadía, A., Abadia, J., Alvarez-Fernández, A. and Briat, J.-F. (2014) Involvement of the ABCG37 transporter in secretion of scopoletin and derivatives by Arabidopsis roots in response to iron deficiency. New Phytol. 201, 155-167 CrossRef PubMed

96 Ji, H., Peng, Y., Meckes, N., Allen, S., Stewart, C.N. and Traw, M.B. (2014) ATP-dependent binding cassette transporter G family member 16 increases plant tolerance to abscisic acid and assists in basal resistance against Pseudomonos syringae DC3000. Plant Physiol. 166 879-888 CrossRef PubMed

97 Kuromori, T., Miyaji, T., Yabuuchi, H., Shimizu, H., Sugimoto, E., Kamiya, A., Moriyama, Y. and Shinozaki, K. (2010) ABC transporter AtABCG25 is involved in abscisic acid transport and responses. Proc. Natl. Acad. Sci. U.S.A. 107, 2361-2366 CrossRef PubMed

98 Piper, P., Mahé, Y., Thompson, S., Pandjaitan, R., Holyoak, C., Egner, R., Mühlbauer, M., Coote, P. and Kuchler, K. (1998) The pdr12 ABC transporter is required for the development of weak organic acid resistance in yeast. EMBO J. 17, 4257-4265 CrossRef PubMed

99 Decottignies, A. and Goffeau, A. (1997) Complete inventory of the yeast $A B C$ proteins. Nat. Genet. 15, 137-145 CrossRef PubMed

100 Kobae, Y., Sekino, T., Yoshioka, H., Nakagawa, T., Martinoia, E. and Maeshima, M. (2006) Loss of AtPDR8, a plasma membrane ABC transporter of Arabidopsis thaliona, causes hypersensitive cell death upon pathogen infection. Plant Cell Physiol. 47, 309-318 CrossRef PubMed

101 Benschop, J.J., Mohammed, S., O'Flaherty, M., Heck, A.J.R., Slijper, M and Menke, F.L.H. (2007) Quantitative phosphoproteomics of early elicitor signaling in Arabidopsis. Mol. Cell. Proteomics 6, 1198-1214 CrossRef PubMed

102 Peck, S.C. (2006) Phosphoproteomics in Arabidopsis: moving from empirical to predictive science. J. Exp. Bot. 57, 1523-1527 CrossRef PubMed

103 Henrichs, S, Wang, B, Fukao, Y, Zhu, J Charrier, L, Bailly, A., Oehring, S.C., Linnert, M., Weiwad, M., Endler, A. et al. (2012) Regulation of ABCB1/PGP1-catalysed auxin transport by linker phosphorylation. EMBO J. 31, 2965-2980 CrossRef PubMed

104 Galván-Ampudia, C.S. and Offringa, R. (2007) Plant evolution: AGC kinases tell the auxin tale. Trends Plant Sci. 12, 541-547 CrossRef PubMed

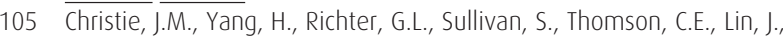
Titapiwatanakun, B., Ennis, M., Kaiserli, E., Lee, O.R. et al. (2011) phot1 inhibition of ABCB19 primes lateral auxin fluxes in the shoot apex required for phototropism. PLoS Biol. 9, e1001076 CrossRef PubMed
106 Rademacher, E.H. and Offringa, R. (2012) Evolutionary adaptations of plant AGC kinases: from light signaling to cell polarity regulation. Front. Plant Sci. 3, 250 CrossRef PubMed

107 Peer, W.A and Murphy, A.S. (2007) Flavonoids and auxin transport: modulators or regulators? Trends Plant Sci. 12, 556-563 CrossRef Pubmed

108 Bailly, A Sovero, V Vincenzetti, V Santelia, D Bartnik, D Koenig, B.W., Mancuso, S., Martinoia, E. and Geisler, M. (2008) Modulation of P-glycoproteins by auxin transport inhibitors is mediated by interaction with immunophilins. J. Biol. Chem. 283, 21817-21826 CrossRef PubMed

109 Sheppard, D.N. and Welsh, M.J. (1999) Structure and function of the CFTR chloride channel. Physiol. Rev. 79, S23-S45 PubMed

110 Cho, M., Henry, E.M., Lewis, D.R., Wu, G., Muday, G.K. and Spalding, E.P. (2014) Block of ATP-binding cassette B19 ion channel activity by 5-nitro-2-(3-phenylpropylamino)-benzoic acid impairs polar auxin transport and root gravitropism. Plant Physiol. 166, 2091-2099 CrossRef Pubmed

111 Kamphausen, T, Fanghänel, I. Neumann, D, Schulz, B. and Rahfeld, J.-U. (2002) Characterization of Arabidopsis thaliono At FKBP42 that is membrane-bound and interacts with Hsp90. Plant J. 32, 263-276 CrossRef PubMed

112 Geisler, M. and Bailly, A. (2007) Tête-à-tête: the function of FKBPs in plant development. Trends Plant Sci. 12, 465-473 CrossRef PubMed

113 Geisler, M., Girin, M., Brandt, S., Vincenzetti, V., Plaza, S., Paris, N., Kobae, Y., Maeshima, M., Billion, K., Kolukisaoglu, U.H. et al. (2004) Arabidopsis immunophilin-like TWD1 functionally interacts with vacuolar ABC transporters. Mol. Biol. Cell 15, 3393-3405 CrossRef PubMed

114 Michniewicz, M., Zago, M.K., Abas, L., Weijers, D., Schweighofer, A. Meskiene, I., Heisler, M.G., Ohno, C., Zhang, J., Huang, F. et al. (2007) Antagonistic regulation of PIN phosphorylation by PP2A and PINOID directs auxin flux. Cell 130, 1044-1056 CrossRef PubMed

115 Wang, B., Henrichs, S. and Geisler, M. (2012) The AGC kinase, PINOID, blocks interactive ABCB/PIN auxin transport. Plant Signal. Behav. 7 1515-1517 CrossRef PubMed

116 Nühse, T.S., Stensballe, A., Jensen, O.N. and Peck, S.C. (2004) Phosphoproteomics of the Arabidopsis plasma membrane and a new phosphorylation site database. Plant Cell 16, 2394-3405 CrossRef PubMed

117 See, R.H., Caday-Malcolm, R.A., Singaraja, R.R., Zhou, S., Silverston, A., Huber, M.T., Moran, J., James, E.R., Janoo, R., Savill, J.M. et al. (2002) Protein kinase A site-specific phosphorylation regulates ATP-binding cassette A1 (ABCA1)-mediated phospholipid efflux. J. Biol. Chem. 277, 41835-41842 CrossRef PubMed

118 Li, Y., Salter-Cid, L., Vitiello, A., Preckel, T., Lee, J.D., Angulo, A., Cai, Z., Peterson, P.A. and Yang, Y. (2000) Regulation of transporter associated with antigen processing by phosphorylation. J. Biol. Chem. 275, 24130-24135 CrossRef PubMed

119 Picciotto, M.R., Cohn, J.A., Bertuzzi, G., Greengard, P. and Nairn, A.C. (1992) Phosphorylation of the cystic fibrosis transmembrane conductance regulator. J. Biol. Chem. 267, 12742-12752 PubMed

120 Townsend, R.R., Lipniunas, P.H., Tulk, B.M. and Verkman, A.S. (1996) Identification of protein kinase A phosphorylation sites on NBD1 and R domains of CFTR using electrospray mass spectrometry with selective phosphate ion monitoring. Protein Sci. 5, 1865-1873 CrossRef PubMed

121 Neville, D.C., Rozanas, C.R., Price, E.M., Gruis, D.B., Verkman, A.S. and Townsend, R.R. (1997) Evidence for phosphorylation of serine 753 in CFTR using a novel metal-ion affinity resin and matrix-assisted laser desorption mass spectrometry. Protein Sci. 6, 2436-2445 CrossRef Pubmed

122 Gadsby, D.C. and Nairn, A.C. (1999) Control of CFTR channel gating by phosphorylation and nucleotide hydrolysis. Physiol. Rev. 79, S77-S107 PubMed

123 Wilkinson, D.J., Strong, T. V., Mansoura, M.K., Wood, D.L., Smith, S.S., Collins, F.S. and Dawson, D.C. (1997) CFTR activation: additive effects of stimulatory and inhibitory phosphorylation sites in the R domain. Am. J. Physiol. Lung Cell. Mol. Physiol. 273, L127-L133

124 Ribalet, B. (2000) Regulation of cloned ATP-sensitive K channels by phosphorylation, mgadp, and phosphatidylinositol bisphosphate (PIP2): a study of channel rundown and reactivation. J. Gen. Physiol. 116, 391-410 CrossRef PubMed

125 Shi, Y., Wu, Z., Cui, N., Shi, W., Yang, Y., Zhang, X., Rojas, A., Ha, B.T. and jiang, C. (2007) PKA phosphorylation of SUR2B subunit underscores vascular KATP channel activation by beta-adrenergic receptors. Am. J. Physiol. Regul. Integr. Comp. Physiol. 293, R1205-R1214 CrossRef PubMed 
126 Quinn, K. V, Giblin, J.P. and Tinker, A. (2004) Multisite phosphorylation mechanism for protein kinase A activation of the smooth muscle ATP-sensitive $\mathrm{K}^{+}$channel. Circ. Res. 94, 1359-1366 CrossRef PubMed

127 Tanaka, A.R., Tanabe, K., Morita, M., Kurisu, M., Kasiwayama, Y., Matsuo, M., Kioka, N., Amachi, T., Imanaka, T. and Ueda, K. (2002) ATP binding/hydrolysis by and phosphorylation of peroxisomal ATP-binding cassette proteins PMP70 (ABCD3) and adrenoleukodystrophy protein (ABCD1). J. Biol. Chem. 277 40142-40147 CrossRef PubMed
128 Xie, Y., Xu, K., Linn, D.E., Yang, X., Guo, Z., Shimelis, H., Nakanishi, T, Ross, D.D., Chen, H., Fazli, L. et al. (2008) The 44-kDa Pim-1 kinase phosphorylates BCRP/ABCG2 and thereby promotes its

multimerization and drug-resistant activity in human prostate cancer cells. J. Biol. Chem. 283, 3349-3356 CrossRef PubMed

doi:10.1042/BST20150128 2 